\title{
Ecosystem Impacts of Exotic Plants Can Feed Back to Increase Invasion in Western US Rangelands
}

\section{By Valerie T. Eviner, Sarah A. Hoskinson, and Christine V. Hawkes}

I nvasive, nonnative plant species have become one of the most pressing rangeland management issues. In the western United States (the 17 US states from North Dakota, south to Texas, and west to the Pacific coast), 51 million hectares of rangeland are now dominated by invasive plants considered to be noxious weeds. ${ }^{1}$ In over two-thirds of western rangelands, nonnative annual grasses account for $50-85 \%$ of vascular plant cover. ${ }^{2}$ Invasive plants have large negative impacts on the prevalence and diversity of native species, and many decrease livestock production through decreases in forage quantity and/or quality (Table 1). Invasive species on US rangelands have an estimated annual cost of US $\$ 2$ billion $^{3}$ due to lost production and costs of control efforts. There are also hidden costs associated with invasive species in the form of degraded ecosystem services-key functions provided by ecosystems that benefit humans (e.g., water provisioning, flood control, erosion control, carbon storage, nutrient supply, climate regulation). In some cases, invasive species change ecosystem processes in ways that are self-reinforcing, making the system more suitable for the invader than for the previous inhabitants, in what is known as a positive feedback loop. The combination of degraded ecosystem properties and positive feedbacks can make invasive plant control and rangeland restoration much more challenging because in these cases, it is not sufficient to simply remove the invaders. The ecosystem impacts of invasive species can persist long after the plants have been removed, and when this occurs, the system can remain vulnerable to reinvasion until the ecosystem effects are mitigated or reversed. We review the ecosystem impacts of the current major rangeland invaders in the western United States, discuss the potential for these ecosystem changes to further promote invasion through positive feedbacks, and suggest strategies to address persistent ecosystem effects in order to enhance invasive plant control and restoration of native (or otherwise desirable) plant communities.

\section{Ecosystem Impacts of Plant Invasions}

Most of the major rangeland invaders in the western United States have large impacts on at least some aspects of ecosystem function, ranging from forage productivity to soil and water quality ${ }^{1}$ (Table 1$)$. Invasive plants in western rangelands typically reduce livestock production by $30-75 \%$ (however, not all invasive plants are detrimental to livestock production, and the effects of a given invader can be beneficial to some livestock species but detrimental to others; Table 1). Although forage quality and production are the most immediate concerns for ranchers, invasive species can also change many other ecosystem characteristics that can negatively impact both the ranch itself and the surrounding areas that rely on ecosystem services provided by rangelands. These ecosystem services include regulation of water flow and quality, soil fertility, soil carbon storage, and wildlife habitat. Water use by yellow starthistle, for example, can remove $15-25 \%$ of annual precipitation, decreasing soil water availability for other plants and ultimately reducing downstream water flow. In California's Sacramento River watershed alone, the costs of lost water associated with yellow starthistle amount to US\$16-75 million annually. ${ }^{4}$ Medusahead has been shown to decrease soil carbon stores, which can have major implications for those seeking credits for carbon sequestration on rangelands. Goatgrass, cheatgrass, medusahead, and spotted knapweed can reduce nitrogen recycling rates, thus potentially limiting rangeland productivity because nitrogen is the most commonly limiting nutrient to plant growth in these systems. Even when invaders do not alter the total amount of soil resources, they can change the timing of resource availability, restricting which plant species have access to soil resources. ${ }^{5}$ 


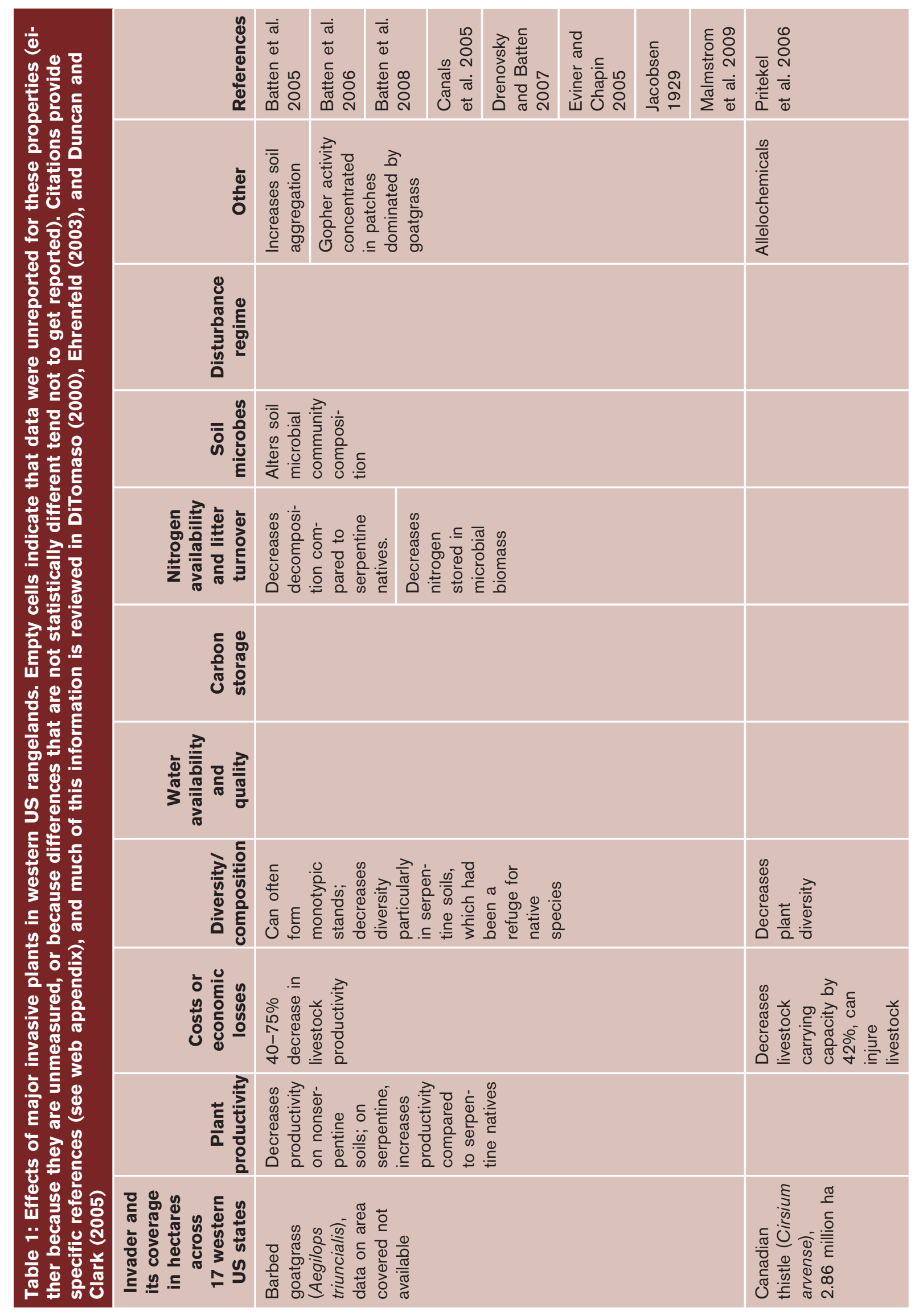




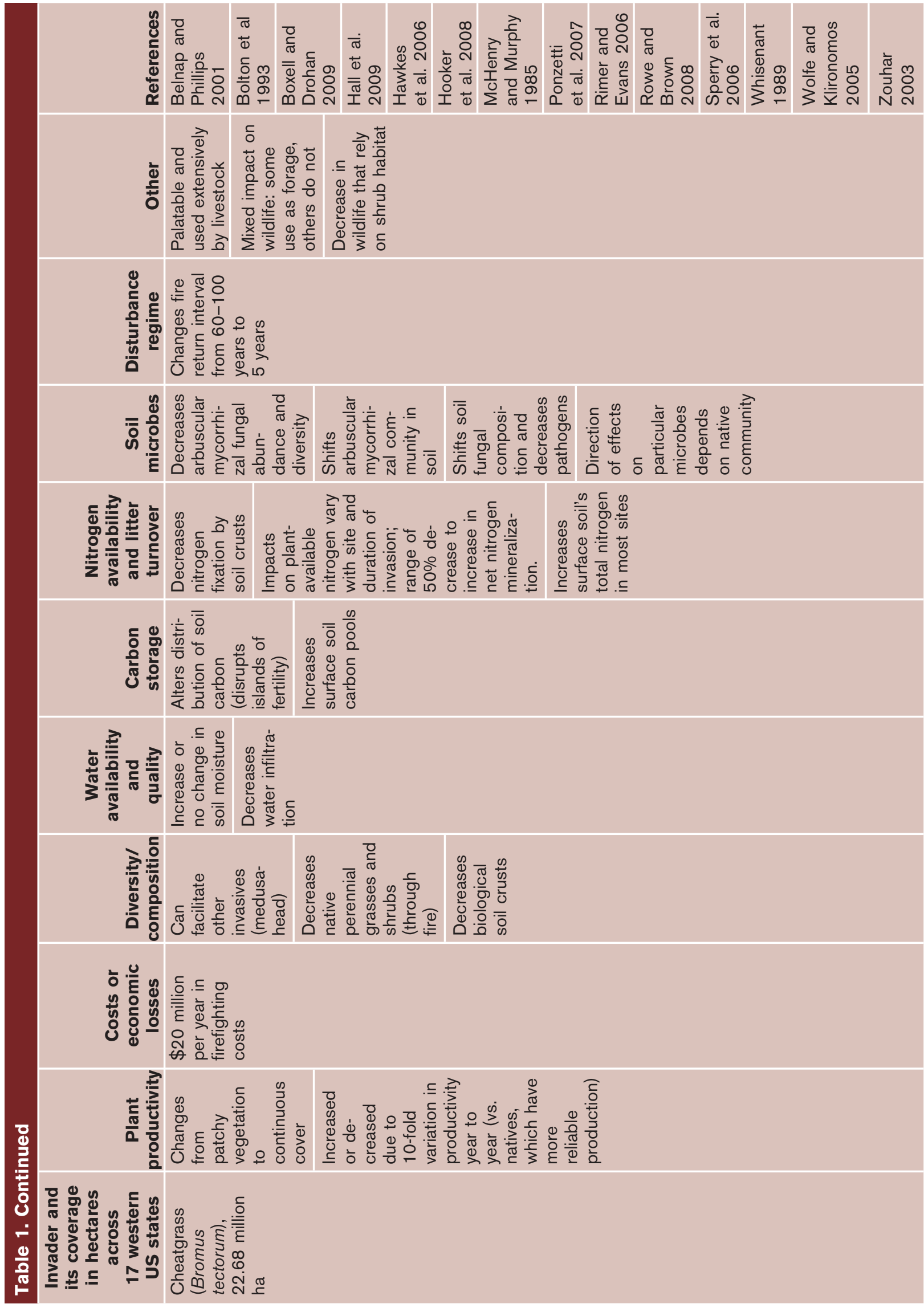




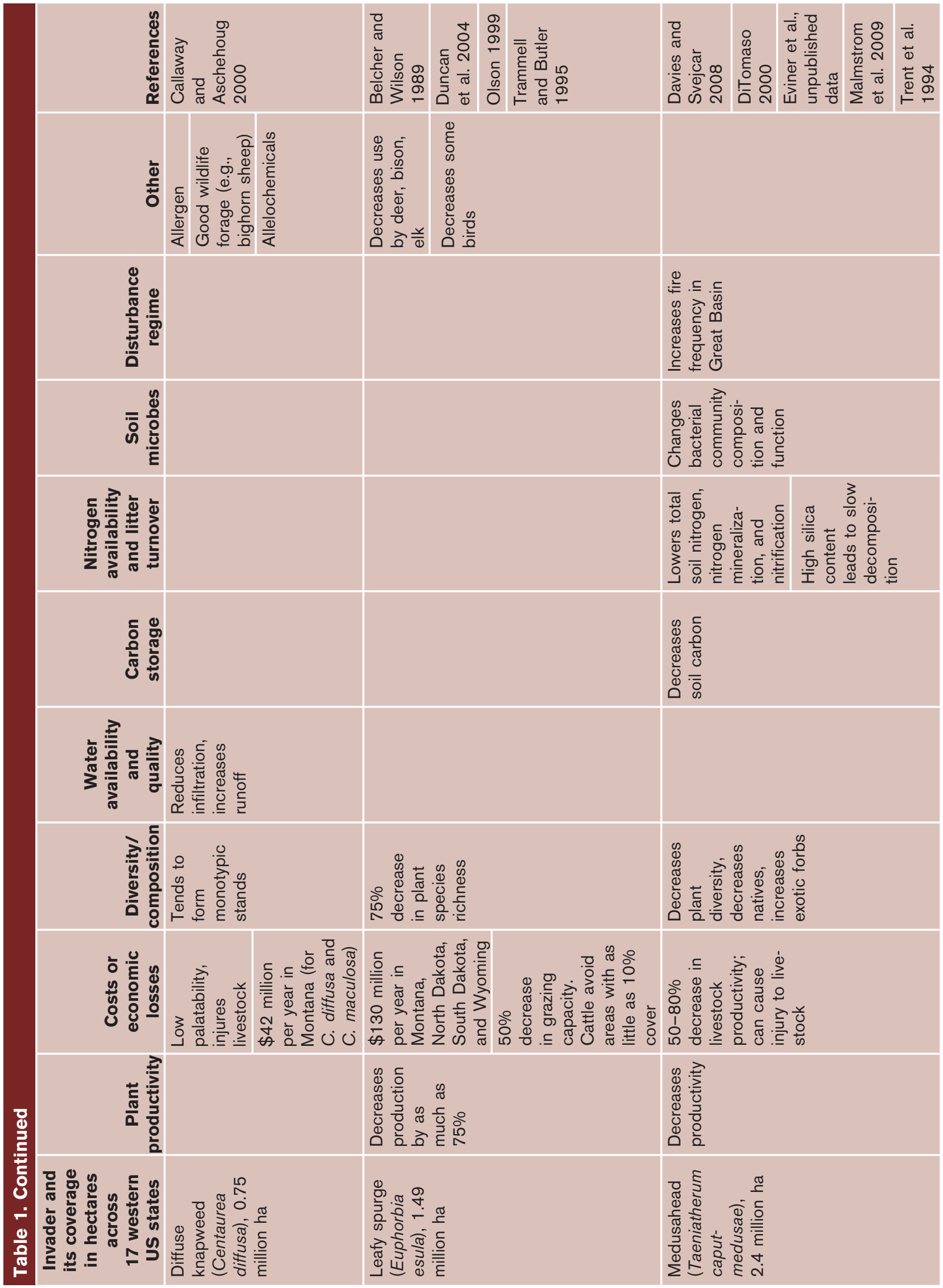




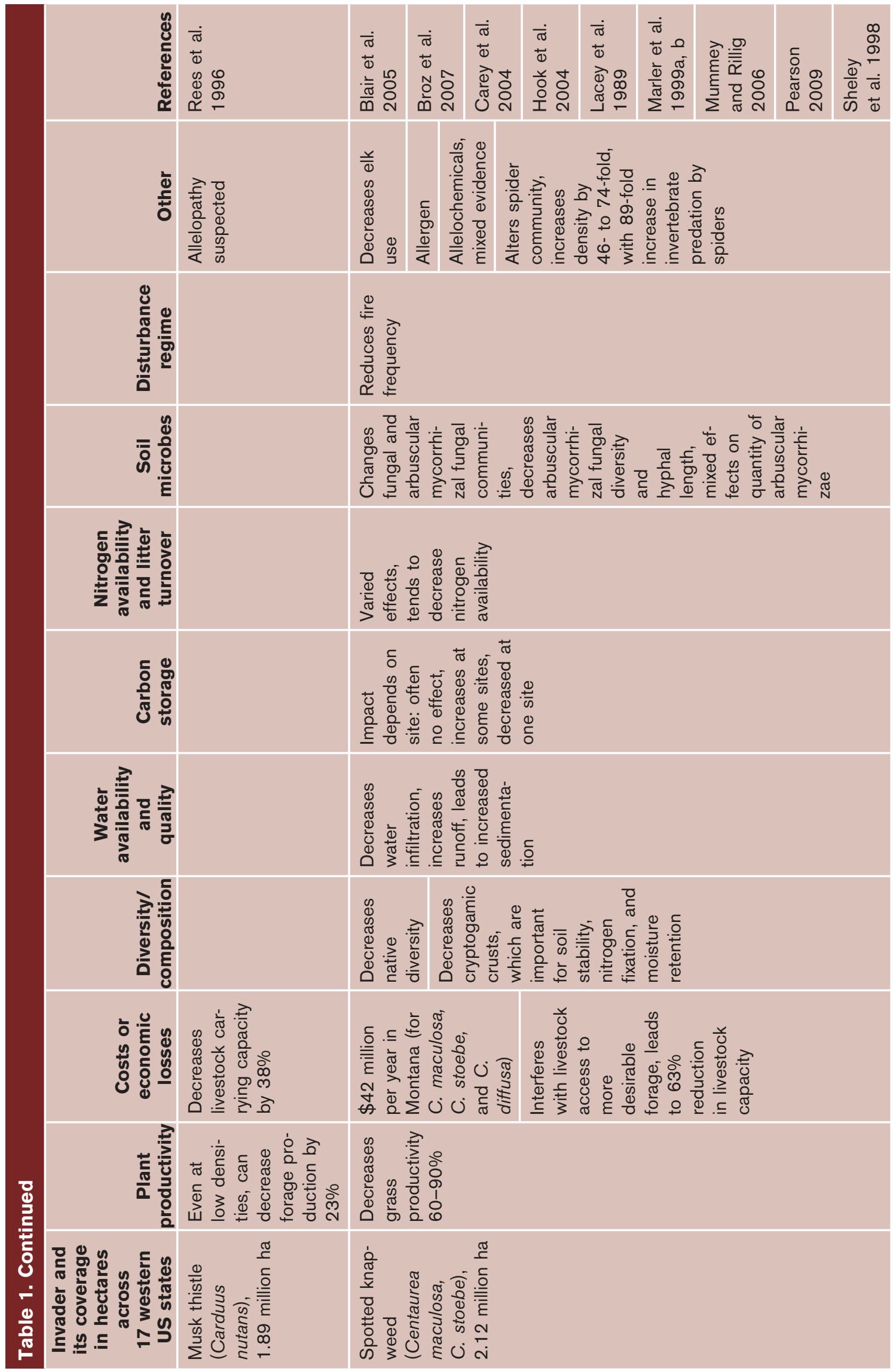




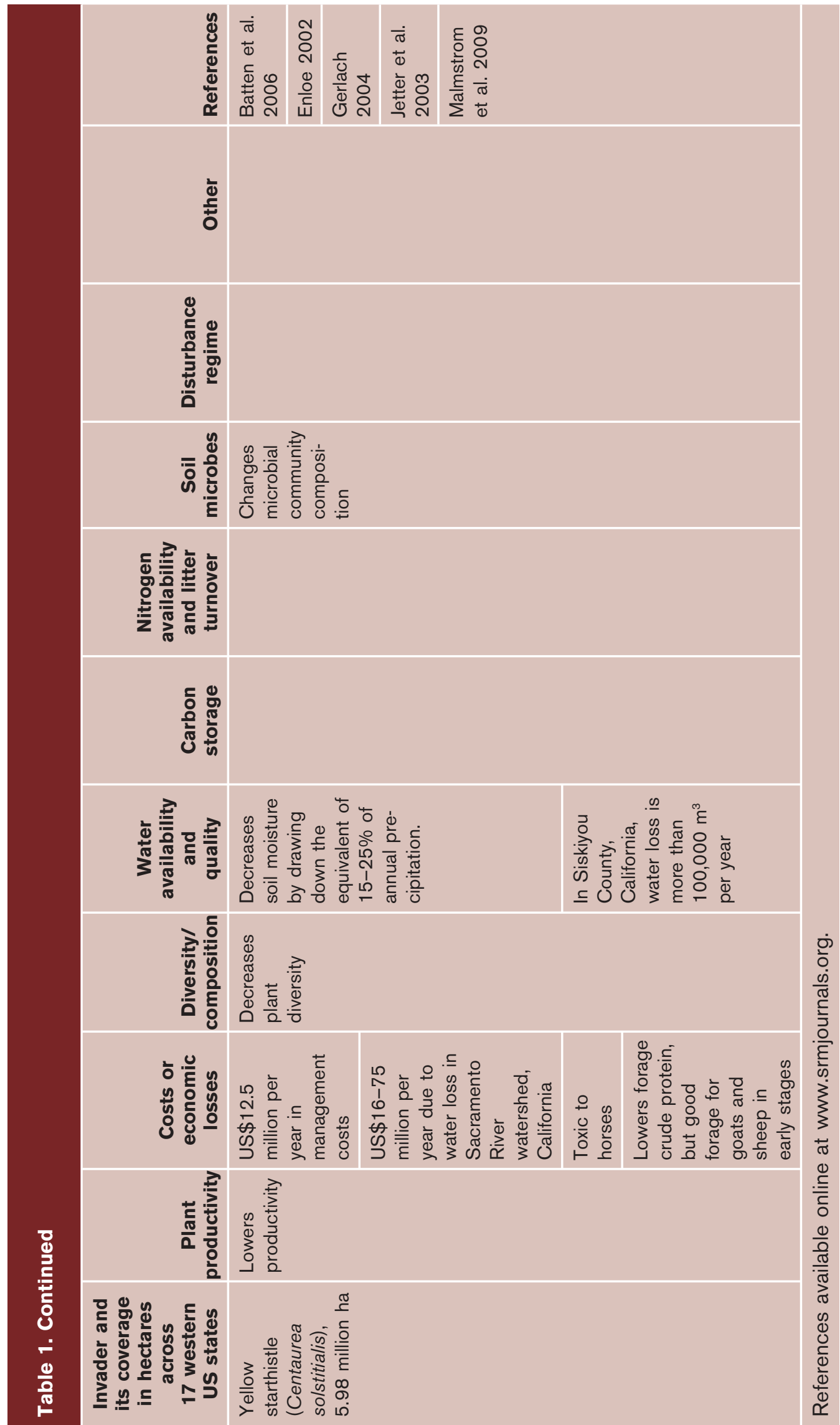


Some ecosystem impacts of invasive species may be rapidly reversible upon removal of the invader. For example, decreased soil water availability caused by high plant transpiration rates should reverse quickly once the invasive plant is removed. In contrast, many invader-induced ecosystem effects can persist even after invasive removal, a concept known as legacy effects. For species that alter soil properties such as soil structure, water infiltration, water holding capacity, carbon storage, nitrogen availability, and so forth, it may take from months to decades to reverse these changes even with active management. ${ }^{6}$ Extensive erosion of topsoil in invaded systems, for example, can take decades to centuries to reverse via soil formation processes and the gradual buildup of organic matter by the restored plant community.

Understanding the ecosystem impacts of key invasive plants in western US rangelands can be difficult because even for a given species, ecosystem effects are often not constant but vary with site conditions, invader prevalence, and duration of the invasion. ${ }^{5,7,8}$ Continued research into the context-dependence of invasive species effects will help us better predict which sites will be most impacted by a particular invader, which ecosystem processes will need to be restored at a given site, and how these ecosystem effects change over time-giving us critical tools for prioritizing our eradication and restoration efforts.

\section{Feedback Effects of Plant Invasions}

Although the ecosystem effects of invasive plants are a concern in their own right, invaders can also change the soil conditions to such an extent that the new conditions alter which plant species can grow successfully at that site. Feedback effects, where a change in plant composition alters conditions that can further alter the plant community, can be either positive or negative. In a positive feedback, the effects of invasive plants on ecosystem properties will further promote the persistence and growth of the invader. In a negative feedback, changes to the ecosystem caused by invasive plants promote other species and thereby limit abundance of the invader. Feedbacks are typically mediated through changes in soil biota, microenvironment, disturbance regime, and/or the soil physical or chemical environment. ${ }^{9,10}$

In general, feedbacks play an important role in community dynamics. In native communities, negative feedbacks are most common, and can decrease plant biomass by an average of $37 \% .{ }^{11}$ Invasive plants are less likely to have negative feedbacks and are more likely to alter soils in ways that increase their own prevalence and biomass (by an average of 43\%). ${ }^{6,11,12}$ In some cases, a given invasive plant alters the soil to benefit other invaders, as well as itself. For example, cheatgrass invasion can make a system more vulnerable to medusahead, and medusahead can increase the prevalence of exotic forbs (Table 1).

Positive feedbacks are common for a number of invasive species in western US rangelands, making their control a greater challenge (Table 2). Many of these invasive plants alter soil biota in ways that favor themselves, or inhibit natives more strongly than themselves. For example, Italian thistle decreases densities of symbiotic arbuscular mycorrhizal fungi, which limits the growth of native forb species. Black mustard displays a different type of feedback strategy; it inhibits native grasses by increasing consumption of the native species by small mammals. The effects of this feedback extend up to $30 \mathrm{~m}$ away from mustard patches. Rangeland invaders also generate feedbacks through changes in the fire regime (cheatgrass), changes in soil nitrogen availability (cheatgrass), and addition of allelochemicals (knapweed) that inhibit growth of other plant species (Table 2). Native communities may also resist invasion by altering soils in ways that suppress the growth of invasive species. ${ }^{13}$

The study of feedbacks created by invasive species is still a relatively new field, and although it is clear that feedbacks can play an important role in invasions, not all invaderinduced ecosystem changes will feed back to benefit invaders. Just as the ecosystem impacts of invaders can be context-dependent, the strength and direction (positive or negative) of feedbacks can also vary with environmental conditions, the amount of time that the invader has been present, and with which plant species are interacting.

\section{Management Considerations}

Removing an invasive species through burning, grazing, or herbicide is a common and necessary starting point, but in some cases, successful management requires disruption of invader-induced soil changes, which can persist for weeks to decades after the invasive plant has been removed. ${ }^{6}$ Without management to reverse the effects of invasive species on soils, the system can often remain susceptible to reinvasion. Because plant-soil feedbacks operate through many mechanisms, there is no easy, one-size-fits-all management plan. Some of the common management practices that have the potential to alter plant-soil feedbacks in favor of native and other desirable species include selecting plants for restoration that can reverse the ecosystem impacts of invasive species, manipulating soil microbes, and adding carbon and charcoal to soil (described below and in Table 3). For these practices to be successful, we must identify the mechanisms driving the feedbacks and select the approaches that have the greatest likelihood of interfering with those specific mechanisms. These tools have been effective in controlling some invaders under specific conditions, but also have failed to work or even increased the prevalence of invaders (Table 3). Mitigating feedbacks is a relatively new approach, and a close collaboration is required between managers and researchers in order to rapidly fine-tune these tools for effective management of invaders.

\section{Selection of Intermediate Plant Species for Restoration}

Although restoration often aims to reestablish the preinvaded plant community, this may not be an immediately feasible goal if invader-induced feedbacks are strong enough to prevent the original native species from persisting long 
Table 2. Feedbacks impacting invasive plants in western US rangelands

\begin{tabular}{|c|c|c|c|c|}
\hline $\begin{array}{l}\text { Invader, study } \\
\text { location }\end{array}$ & $\begin{array}{l}\text { What does the } \\
\text { invader change? }\end{array}$ & $\begin{array}{l}\text { How do these changes } \\
\text { affect native vs. invasive } \\
\text { species? }\end{array}$ & $\begin{array}{l}\text { What does this mean for } \\
\text { managing the invader? }\end{array}$ & References \\
\hline $\begin{array}{l}\text { Barbed goatgrass } \\
\text { (Aegilops triuncialis), } \\
\text { California }\end{array}$ & $\begin{array}{l}\text { Changes soil } \\
\text { microbial community } \\
\text { composition on } \\
\text { serpentine soils }\end{array}$ & $\begin{array}{l}\text { Decreases growth and } \\
\text { flowering time of Lasthenia } \\
\text { californica (native forb) }\end{array}$ & $\begin{array}{l}\text { Need to alter soil community } \\
\text { for successful restoration of } \\
\text { this native species }\end{array}$ & $\begin{array}{l}\text { Batten et al. } \\
2008\end{array}$ \\
\hline $\begin{array}{l}\text { Crested wheatgrass } \\
\text { (Agropyron } \\
\text { cristatum), Great } \\
\text { Plains region }\end{array}$ & Changes soil biota & $\begin{array}{l}\text { Increases its own growth } \\
\text { and decreases growth of } \\
\text { some native forbs (also } \\
\text { increases growth of the } \\
\text { invasive Bromus inermis) }\end{array}$ & $\begin{array}{l}\text { Consider planting native } \\
\text { species that are relatively } \\
\text { insensitive to soils altered by } \\
\text { the invader }\end{array}$ & $\begin{array}{l}\text { Jordan et al. } \\
2008\end{array}$ \\
\hline $\begin{array}{l}\text { Black mustard } \\
\text { (Brassica nigra), } \\
\text { California }\end{array}$ & $\begin{array}{l}\text { Increases } \\
\text { consumption of the } \\
\text { native Nassella } \\
\text { pulchra by native } \\
\text { small mammals }\end{array}$ & $\begin{array}{l}\text { Curtails establishment of } \\
N \text {. pulchra within } 30 \mathrm{~m} \text { of } \\
B \text {. nigra patches }\end{array}$ & $\begin{array}{l}\text { May not be able to } \\
\text { reestablish } N \text {. pulcha close } \\
\text { to } B \text {. nigra }\end{array}$ & $\begin{array}{l}\text { Orrock et al. } \\
2008\end{array}$ \\
\hline $\begin{array}{l}\text { Smooth brome } \\
\text { (Bromus inermis), } \\
\text { Great Plains region }\end{array}$ & Changes soil biota & $\begin{array}{l}\text { Increases its own growth } \\
\text { and decreases some native } \\
\text { forbs (also increases growth } \\
\text { of the invasive Euphorbia) }\end{array}$ & $\begin{array}{l}\text { Consider planting native } \\
\text { species that are relatively } \\
\text { insensitive to soils altered by } \\
\text { the invader }\end{array}$ & $\begin{array}{l}\text { Jordan et al. } \\
2008\end{array}$ \\
\hline $\begin{array}{l}\text { Cheatgrass (Bromus } \\
\text { tectorum), Great } \\
\text { Basin }\end{array}$ & $\begin{array}{l}\text { Increases fire } \\
\text { frequency }\end{array}$ & $\begin{array}{l}\text { Decreases survival of native } \\
\text { perennials }\end{array}$ & $\begin{array}{l}\text { Must decrease fire } \\
\text { frequency for restoration of } \\
\text { perennials }\end{array}$ & $\begin{array}{l}\text { Knick and } \\
\text { Rotenberry } \\
1997\end{array}$ \\
\hline $\begin{array}{l}\text { Cheatgrass (Bromus } \\
\text { tectorum), Utah }\end{array}$ & $\begin{array}{l}\text { Increases soil nitrate } \\
\text { deep in the soil } \\
\text { profile through } \\
\text { leaching from litter, } \\
\text { inhibition of nitrogen } \\
\text { supply from soil } \\
\text { crusts }\end{array}$ & $\begin{array}{l}\text { Natives cannot access this } \\
\text { deep-soil nitrogen source }\end{array}$ & $\begin{array}{l}\text { Need to restore surface soil } \\
\text { nitrogen availability for } \\
\text { reestablishment of natives }\end{array}$ & $\begin{array}{l}\text { Sperry et al. } \\
2006\end{array}$ \\
\hline $\begin{array}{l}\text { Italian thistle } \\
\text { (Carduus } \\
\text { pycnocephalus), } \\
\text { California }\end{array}$ & $\begin{array}{l}\text { Decreases AMF } \\
\text { densities }\end{array}$ & $\begin{array}{l}\text { Decreases growth of a } \\
\text { native forb (Gnaphalium } \\
\text { californicum); C. } \\
\text { pycnocephalus grows best } \\
\text { in soils without AMF and } \\
\text { in nonnative soils }\end{array}$ & $\begin{array}{l}\text { If species that do not } \\
\text { maintain AMF communities } \\
\text { invade an area, it may be } \\
\text { difficult to restore the area } \\
\text { to a native community that is } \\
\text { reliant on AMF, potential for } \\
\text { use of native AMF inoculum }\end{array}$ & $\begin{array}{l}\text { Vogelsang } \\
\text { and Bever } \\
2009\end{array}$ \\
\hline \multirow{4}{*}{$\begin{array}{l}\text { Knapweed } \\
\text { (Centaurea maculosa } \\
\text { and C. diffusa), } \\
\text { Intermountain West }\end{array}$} & \multirow[t]{4}{*}{$\begin{array}{l}\text { Releases } \\
\text { allelochemicals }\end{array}$} & \multirow{4}{*}{$\begin{array}{l}\text { Decreases growth of some } \\
\text { native species, but species } \\
\text { may be able to evolve } \\
\text { resistance to allelochemicals } \\
\text { over the long term }\end{array}$} & \multirow{4}{*}{$\begin{array}{l}\text { Centaurea maculosa and } \\
\text { C. diffusa may exclude } \\
\text { native species when they } \\
\text { invade a new area, but } \\
\text { plants that have been } \\
\text { exposed to these invaders } \\
\text { for a long time may be less } \\
\text { affected }\end{array}$} & $\begin{array}{l}\text { Blair et al. } \\
2005\end{array}$ \\
\hline & & & & $\begin{array}{l}\text { Callway and } \\
\text { Aschehoug } \\
2000\end{array}$ \\
\hline & & & & $\begin{array}{l}\text { Callaway and } \\
\text { Vivanco } 2007\end{array}$ \\
\hline & & & & $\begin{array}{l}\text { Thorpe et al. } \\
2009\end{array}$ \\
\hline
\end{tabular}




\begin{tabular}{|c|c|c|c|c|}
\hline $\begin{array}{l}\text { Invader, study } \\
\text { location }\end{array}$ & $\begin{array}{l}\text { What does the } \\
\text { invader change? }\end{array}$ & $\begin{array}{l}\text { How do these changes } \\
\text { affect native vs. invasive } \\
\text { species? }\end{array}$ & $\begin{array}{l}\text { What does this mean for } \\
\text { managing the invader? }\end{array}$ & References \\
\hline \multirow{2}{*}{$\begin{array}{l}\text { Spotted knapweed } \\
\text { (Centaurea } \\
\text { maculosa), Montana }\end{array}$} & \multirow[t]{2}{*}{ Alters AMF function } & \multirow{2}{*}{$\begin{array}{l}\text { Enhances ability for C. } \\
\text { maculosa to competitively } \\
\text { suppress Festuca idahoen- } \\
\text { sis (native bunchgrass); } \\
\text { C. maculosa parasitizes F. } \\
\text { idahoensis through AMF, } \\
\text { increasing invader growth } \\
87-168 \% \text { in presence of } \\
\text { AMF }\end{array}$} & \multirow{2}{*}{$\begin{array}{l}\text { Further study is needed, } \\
\text { may need to suppress or } \\
\text { alter AMF community }\end{array}$} & $\begin{array}{l}\text { Carey et al. } \\
2004\end{array}$ \\
\hline & & & & $\begin{array}{l}\text { Marler et al. } \\
1999 a, b\end{array}$ \\
\hline $\begin{array}{l}\text { Leafy spurge } \\
\text { (Euphorbia esula), } \\
\text { Great Plains region }\end{array}$ & Changes soil biota & $\begin{array}{l}\text { Decreases growth of native } \\
\text { forbs, as well as other } \\
\text { invaders }\end{array}$ & $\begin{array}{l}\text { Consider planting native } \\
\text { species that are relatively } \\
\text { insensitive to soils altered by } \\
\text { the invader }\end{array}$ & $\begin{array}{l}\text { Jordan et al. } \\
2008\end{array}$ \\
\hline
\end{tabular}

enough to alter soil conditions. Instead, a multistage successional approach can be employed by initially planting species that are more tolerant of the invaded soil conditions. Once these initial plantings ameliorate the invaded soil conditions, the native community that is ultimately desired can be seeded in (Tables 2 and 3). This approach is similar to agricultural use of cover crops to disrupt pathogen cycles, increase soil fertility, and build up organic matter. In Australian grasslands, a specific grass species is used to reduce high levels of soil nitrate created by invasive species, which prevents reinvasion (Table 3). To prevent spotted knapweed reinvasion after weed control measures, plant species are being tested for resistance to knapweed's allelochemicals (Table 3). The establishment of these resistant species can prevent knapweed from reinvading and eventually facilitate the establishment of native species that are susceptible to allelochemicals.

\section{Soil Microbial Communities as a Tool for Restoration}

Soil biota can strongly affect plant success, but their manipulation is not straightforward and our understanding of these interactions is still rudimentary. Two groups that are often targeted in restoration efforts are mycorrhizal fungi and biological soil crusts (Table 3). Mycorrhizal fungi are available as a commercial inoculum, but this is primarily a tool for severely degraded sites that have little to no soil biota remaining. In systems where native plants have a stronger benefit from local mycorrhizas than do invasive plants, a local native mycorrhizal inoculum may be useful if it can be obtained. Biological soil crusts have been used as a tool to enhance native seed germination at the expense of invasive plants and can additionally increase nitrogen availability and soil stability in degraded ecosystems. Attempts to reestablish crusts at large scales using cultured, pelleted algae have had limited success (Table 3).

\section{Carbon Additions to Decrease Soil Nitrogen}

To manage invasive species that increase nutrient availability, carbon additions (e.g., sawdust, sugar) have sometimes been used with the goal of tying up excess soil nitrogen in microbial biomass by stimulating microbial growth. Although this approach can be successful in reducing some invasive species (e.g., diffuse knapweed), its effectiveness in reducing soil nitrogen availability and controlling invasives is variable (Table 3; also see article by Alpert in this issue).

\section{Activated Carbon to Mitigate Allelochemicals}

Activated carbon, also known as activated charcoal, is often used for chemical purification and pollutant removal from water and air because of its ability to efficiently sequester organic compounds on its highly porous surface area. In soils, the effects of activated carbon are not completely understood, but it is believed to play a large role in binding allelochemicals, removing them from the soil solution, and reducing their effects on native plants. The native grass Festuca idahoensis, when grown with spotted knapweed, grew 85\% larger with activated carbon than without (Table 3). A single application of activated carbon combined with native seed additions in ex-arable fields also reversed dominance from invasives such as cheatgrass and diffuse knapweed to natives (largely bluebunch wheatgrass). Allelochemicals generally are short-lived in the soil (hours to days), ${ }^{14}$ suggesting that activated carbon may be most 
Table 3. Some potential management practices for disrupting positive plant-soil feedbacks created by invasive species

\begin{tabular}{|c|c|c|c|}
\hline Management option & Successful management & $\begin{array}{l}\text { Management limitations/ } \\
\text { failures }\end{array}$ & References \\
\hline \multirow{7}{*}{$\begin{array}{l}\text { Successional } \\
\text { approach: rather than } \\
\text { directly planting in } \\
\text { desired plant } \\
\text { community, initially } \\
\text { plant species that } \\
\text { can make system } \\
\text { more amenable to } \\
\text { native reestablishment }\end{array}$} & \multirow{3}{*}{$\begin{array}{l}\text { Use of species that can } \\
\text { decrease soil-available nitrate, } \\
\text { making restoration sites more } \\
\text { resistant to reinvasion and more } \\
\text { conducive to the persistence of } \\
\text { desirable species }\end{array}$} & \multirow{3}{*}{$\begin{array}{l}\text { The ability of species to } \\
\text { decrease soil nitrate may } \\
\text { fluctuate seasonally, creating } \\
\text { windows of opportunities for } \\
\text { invaders }\end{array}$} & Herron et al. 2001 \\
\hline & & & Prober et al. 2005 \\
\hline & & & Prober and Lunt 2009 \\
\hline & \multirow{2}{*}{$\begin{array}{l}\text { Use of species that are } \\
\text { resistant to allelochemicals } \\
\text { (currently being tested) }\end{array}$} & \multirow{2}{*}{$\begin{array}{l}\text { Few species are resistant to } \\
\text { allelochemicals at all life stages, } \\
\text { so diversity of restored } \\
\text { community may be limited } \\
\text { initially }\end{array}$} & Alford et al. 2008 \\
\hline & & & Perry et al. 2005 \\
\hline & \multirow{2}{*}{$\begin{array}{l}\text { Use of species minimally } \\
\text { impacted by invader effects on } \\
\text { soil microbial community }\end{array}$} & \multirow{2}{*}{$\begin{array}{l}\text { Untested, based on studies } \\
\text { that suggest that invader effects } \\
\text { on soil microbes limit } \\
\text { reestablishment of some natives }\end{array}$} & Jordan et al. 2008 \\
\hline & & & Vogelsang and Bever 2009 \\
\hline $\begin{array}{l}\text { Application of } \\
\text { commercial } \\
\text { mycorrhizal inocula }\end{array}$ & $\begin{array}{l}\text { Can increase productivity and } \\
\text { survival of target species, } \\
\text { reduce invasive plant fitness, } \\
\text { and increase soil aggregation }\end{array}$ & $\begin{array}{l}\text { Can also decrease target } \\
\text { species, increase invasive } \\
\text { species, reduce soil carbon }\end{array}$ & $\begin{array}{l}\text { Reviewed in Schwartz et al. } \\
2006\end{array}$ \\
\hline \multirow{5}{*}{$\begin{array}{l}\text { Reestablishment of } \\
\text { biological soil crusts }\end{array}$} & \multirow{5}{*}{$\begin{array}{l}\text { Can increase soil stabilization, } \\
\text { native seed germination, adult } \\
\text { plant establishment, and soil } \\
\text { nutrient availability. Various } \\
\text { inoculation methods exist; most } \\
\text { successful approach requires } \\
\text { destruction of intact crusts for } \\
\text { inoculum used to restore crusts } \\
\text { at local scales }\end{array}$} & \multirow{5}{*}{$\begin{array}{l}\text { Mass culturing and pelletization } \\
\text { of cyanobacteria produce crusts } \\
\text { in lab but not in field tests; } \\
\text { introduction of cyanobacteria } \\
\text { cultured on cloth resulted in } \\
\text { short-term growth at only one of } \\
\text { five sites }\end{array}$} & Reviewed in Bowker 2007 \\
\hline & & & Buttars et al. 1998 \\
\hline & & & Kubecková et al. 2003 \\
\hline & & & Lesica and Shelly 1992 \\
\hline & & & St. Clair et al. 1984 \\
\hline \multirow{3}{*}{$\begin{array}{l}\text { Addition of carbon } \\
\text { (e.g., sawdust, sugar) } \\
\text { to decrease soil } \\
\text { available nitrogen } \\
\text { through microbial } \\
\text { immobilization }\end{array}$} & \multirow{3}{*}{$\begin{array}{l}\text { Can be very effective in } \\
\text { controlling some invaders } \\
\text { (e.g., diffuse knapweed) }\end{array}$} & \multirow{3}{*}{$\begin{array}{l}\text { Can have no impact or increase } \\
\text { other invaders. Carbon additions } \\
\text { do not always decrease } \\
\text { nitrogen (and can sometimes } \\
\text { increase nitrogen). There may } \\
\text { be site-specific threshold levels } \\
\text { of carbon that must be added } \\
\text { to decrease nitrogen }\end{array}$} & Alpert, this issue \\
\hline & & & Blumenthal et al. 2003 \\
\hline & & & Blumenthal 2009 \\
\hline \multirow{4}{*}{$\begin{array}{l}\text { Activated carbon to } \\
\text { sequester } \\
\text { allelochemicals }\end{array}$} & \multirow{4}{*}{$\begin{array}{l}\text { Has been effective with spotted } \\
\text { knapweed, diffuse knapweed, } \\
\text { and cheatgrass }\end{array}$} & \multirow{4}{*}{$\begin{array}{l}\text { Can also increase invaders and/ } \\
\text { or decrease natives. Because } \\
\text { binding is indiscriminate, } \\
\text { additions can decrease } \\
\text { allelochemicals, change nitrogen } \\
\text { availability, and alter microbial } \\
\text { communities, making the } \\
\text { mechanism of impact uncertain }\end{array}$} & Kulmatiski, in press \\
\hline & & & Kulmatiski and Beard 2006 \\
\hline & & & Lau et al. 2008 \\
\hline & & & Ridenour and Callaway 2001 \\
\hline
\end{tabular}


useful to minimize the effects of invaders currently at a site. To ameliorate potential longer-term legacies of allelochemicals deposited through plant litter, ${ }^{14}$ best practices should include removing all invasive plant material from a site. Activated carbon not only binds organic substrates, but can also change soil nitrogen availability, the ratio of carbon to nitrogen in soil, and soil microbial communities, so its effects on soils and plants may be for different reasons in different trials (Table 3).

\section{Summary}

Invasive plants in western US rangelands not only greatly decrease native diversity and cover, but also compromise many ecosystem services, resulting in millions of dollars lost each year due to diminished productivity, water quantity, water quality, erosion control, and other key services. These invader-induced changes to the ecosystem can also benefit the invasive species at the expense of natives, making invasive plant control even more intractable. In cases in which invasive species cause positive feedbacks, simply eradicating invaders will only lead to reinvasion. Thus, management needs to go beyond basic invader control by reversing the changes invaders make to ecosystem properties, with a particular emphasis on soils. There is considerable variation in effects of invasive species across sites and time and our understanding of feedbacks and their management is still developing. Yet there are some underexploited tools that show promise in disrupting plant-soil feedbacks and collaborations between managers and researchers can accelerate our understanding and control of these feedbacks.

\section{Acknowledgments}

Eviner was supported by the National Research Initiative of the USDA Cooperative State Research, Education, and Extension Service Managed Ecosystems Program grant 2007-55101-18215, and Weedy and Invasive Species Program grant 2006-55320-17247. Hawkes was supported by the National Research Initiative of the USDA Cooperative State Research, Education and Extension Service Managed Ecosystems Program, grant 2006-35101-16575. Hoskinson was supported by the California Department of Food and Agriculture Weed Management Area Program, grant 08-0610.

\section{References}

1. Duncan, C., And J. K. Clark [eds.]. 2005. Invasive plants of range and wildlands and their environmental, economic, and societal impacts. Lawrence, KS, USA: Weed Science Society of America. 222 p.

2. Belnap, J., And S. L. Phillips. 2001. Soil biota in an ungrazed grassland: response to annual grass (Bromus tectorum) invasion. Ecological Applications 11:1261-1275.

3. DiTomaso, J. M. 2000. Invasive weeds in rangelands: species, impacts, and management. Weed Science 48:255-265.

4. Gerlach, J. D. 2004. The impacts of serial land-use changes and biological invasions on soil water resources in California, USA. Journal of Arid Environments 57:365-379.

5. Ehrenfeld, J. G. 2003. Effects of exotic plant invasions on soil nutrient cycling processes. Ecosystems 6:503-523.

6. van der Putten, W. H., R. D. Bardgett, P. C. de Ruiter, W. H. G. Hol, K. M. Meyer, T. M. Bezemer, M. A. Bradford, S. Christensen, M. B. Eppinga, T. Fukami, L. Hemerik, J. Molofsky, M. Schadler, C. Scherber, S. Y. Strauss, M. Vos, and D. A. Wardle. 2009. Empirical and theoretical challenges in aboveground-belowground ecology. Oecologia 161:1-14.

7. Strayer, D. L., V. T. Eviner, J. M. Jeschke, and M. L. PACE. 2006. Understanding the long-term effects of species invasions. Trends in Ecology and Evolution 21:645-651.

8. Eviner, V. T., and C. V. Hawkes. 2008. Embracing variability in the application of plant-soil interactions to the restoration of communities and ecosystems. Restoration Ecology 16: 713-729.

9. Ehrenfeld, J. G., B. Ravit, and K. Elgersma. 2005. Feedback in the plant-soil system. Annual Review of Environment and Resources 30:75-115.

10. Reinhart, K. O., and R. M. Callaway. 2006. Soil biota and invasive plants. New Phytologist 170:445-457.

11. Kulmatiski, A., and P. Kardol. 2008. Getting plant-soil feedbacks out of the greenhouse: experimental and conceptual approaches. Progress in Botany 69:449-472.

12. Kulmatiski, A., K. H. Beard, J. Stevens, and S. M. Соввоцd. 2008. Plant-soil feedbacks: a meta-analytical review. Ecology Letters 11:980-992.

13. Kulmatiski, A., K. H. Beard, and J. M. Stark. 2004. Finding endemic soil-based controls for weed growth. Weed Technology 18:1353-1358.

14. Reigosa, M. J., N. Pedrol, and L. Gonzalez. 2006. Allelopathy: a physiological process with ecological implications. Dordrecht, Netherlands: Springer. 637 p.

Authors are Assistant Professor, Dept of Plant Sciences, University of California, Davis, CA 95616, USA, veriner@ucdavis.edu (Eviner); Graduate Student, Graduate Group in Ecology, University of California, Davis, CA 95616, USA (Hoskinson); and Assistant Professor, Section of Integrative Biology, University of Texas, Austin, TX 78712, USA (Hawkes). Additional references available online at www.srmjournals.org. 